УДК 340.12:342.7

\author{
Є. А. Кобрусєва \\ orcid.org/0000-0002-4225-9657 \\ кандидат юридичних наук, \\ доцент кафедри адміністративного і кримінального права \\ Дніпровського начіонального університету ілені Олеся Гончара
}

\title{
ОСОБЛИВОСТІ ПРОВАДЖЕННЯ ЩОДО РОЗГЛЯДУ ТА ВИРІШЕННЯ АДМІНІСТРАТИВНИХ СПРАВ ЩОДО РЕАЛІЗАЦІЇ ПРАВА НА МИРНІ ЗІБРАННЯ
}

Право громадян на мирні зібрання є однією з основних конституційних гарантій ї самовираження, висловлення своїх думок, можливістю відстоювати свої соціальні, економічні та політичні права і прямою конституційною нормою, яка гарантується державою та закріплена в статті 39 Конституції України, відповідно до якої громадяни мають право збиратися мирно, без зброї і проводити збори, мітинги, походи і демонстрації, про проведення яких завчасно сповіщаються органи виконавчої влади чи органи місцевого самоврядування. Водночас слід зазначити: попри підвищення рівня активності громадян у реалізації права на мирні зібрання, що є виявом становлення демократії в нашій країні, вітчизняне законодавство лише частково регламентує порядок реалізації права на мирні зібрання і базується на застарілій нормативній базі, адже наразі відсутній закон, який би регламентував порядок реалізації права громадян на мирні зібрання. Незважаючи на це, для країн з усталеними демократичними традиціями звичайною практикою є визначення міри свободи мирних зібрань у кожному конкретному випадку через залучення механізмів правосуддя. Але в Україні нині спостерігається стійка ситуація неготовності судової системи до оперативного та неупередженого винесення рішень у спорах щодо обмеження права на свободу мирних зібрань, у результаті чого громадяни все частіше звертаються за захистом до Європейського Суду з прав людини. Тому автором акцентується увага на важливості нормативно-правового врегулювання права на мирні зібрання, оскільки це питання стало традиційним протягом усього періоду незалежності.

Україна виокремлюється на тлі Східної Європи як глобальними численними акціями протестів, які призводять до змін влади в країні, так і регіональними акціями зібрань, які впливають на соціально-політичну та економічну ситуації в країні.

Тому нами зосереджується увага на гострих та актуальних питаннях адміністративно-правого регулювання права на мирні зібрання, що бентежать та неодноразово привертають увагу науковців, серед яких: М.О. Баймуратов, В.В. Букач, О.В. Васьковська, Т.І. Гудзь, М.М. Денісова, О.С. Денісова, О.Ю. Дрозд, В.В. Заросило, О.В. Ко- лісник, А.Т. Комзюк, Р.О. Куйбіда, М.І. Логвиненко, С.М. Міщенко та інші.

Проблема дотримання свободи зібрань набула в Україні особливої актуальності через численні акції протесту, які вже неодноразово відбувалися в Україні. Дотепер правове забезпечення права на мирні зібрання продовжує розвиватися неоднорідно і нерідко залежить від соціально-політичної ситуації в країні.

Водночас слід зазначити, що питання адміністративно-правового регулювання права на мирні зібрання та кількість судових спорів щодо реалізації права громадян на мирні зібрання становлять значну та складну практику діяльності адміністративних судів.

Главою 11 Кодексу адміністративного судочинства України (далі - КАСУ) врегульовано порядок процесуального провадження у справах щодо обмеження реалізації права на мирні зібрання, де суб'єктами є органи публічної адміністрації, a came:

- особливості провадження у справах за адміністративними позовами органів виконавчої влади, органів місцевого самоврядування про встановлення обмеження щодо реалізації права на свободу мирних зібрань визначено статтею 280 КАСУ;

- особливості провадження у справах за адміністративними позовами про усунення перешкод та заборону втручання у здійснення права на свободу мирних зібрань визначено статтею 281 КАСУ.

Ч. 4 стаття 46 КАСУ передбачає, що громадяни України, іноземці чи особи без громадянства, їх об'єднання, юридичні особи, які не є суб'єктами владних повноважень, можуть бути відповідачами за адміністративним позовом суб'єкта владних повноважень про встановлення обмежень щодо реалізації права на свободу мирних зібрань (збори, мітинги, походи, демонстрації тощо) [3, с. 2-3].

Згідно 3 ч. 1 статті 280 КАСУ органи виконавчої влади, органи місцевого самоврядування негайно після одержання повідомлення про проведення зборів, мітингів, походів, демонстрацій тощо мають право звернутися до окружного адміністративного суду за своїм місцезнаходженням із позовною заявою про заборону таких заходів чи про інше обмеження права на мирні зібрання (щодо місця, часу їх проведення тощо). 
Закон не встановлюе конкретного строку звернення $з$ такою заявою до суду, однак зумовлює негайне звернення до суду після одержання повідомлення про проведення масового заходу, що не є конкретним аспектом, для подальших маніпуляцій.

Відповідно до ч. 1 статті 281 КАСУ організатор (організатори) зборів, мітингів, походів, демонстрацій чи інших мирних зібрань мають право звернутися до адміністративного суду за місцем проведення цих заходів із позовною заявою про усунення обмежень у реалізації права на мирні зібрання з боку органів виконавчої влади, органів місцевого самоврядування, повідомлених про проведення таких заходів [3, с. 2-3].

Підсудність справ про усунення обмежень у реалізації права на мирні зібрання залежить від статусу відповідача та визначається за правилами предметної підсудності адміністративних справ, установлених статтею 20 КАСУ [3].

Згідно з приписами ч. 2 названої статті справи про усунення обмежень у реалізації права на мирні зібрання підсудні окружним адміністративним судам.

У справах за адміністративними позовами органів виконавчої влади, органів місцевого самоврядування про встановлення обмеження щодо реалізації права на свободу мирних зібрань копію позовної заяви та доданих до неї документів позивач додатково надсилає на адресу електронної пошти, зазначеної в повідомленні про проведення мирного зібрання, та оприлюднює на своєму офіційному вебсайті. До позовної заяви позивачем додаються докази виконання вимог цієї частини. Позовна заява, яка надійшла пізніше ніж за 24 години до часу проведення заходів, визначених ч. 1 цієї статті, залишається без розгляду, що уможливлює однозначне трактування рішення.

Згідно з приписами статей 280,281 КАСУ про відкриття провадження у справі за позовом про обмеження права на мирні зібрання або про усунення обмежень у реалізації права на мирні зібрання, дату, час та місце розгляду справи суд негайно повідомляє позивача та відповідача (відповідний орган виконавчої влади, орган місцевого самоврядування та організатора (організаторів) зборів, мітингів, походів, демонстрацій чи інших мирних зібрань) [3; 4].

На відміну від позовів за зверненням суб'єкта владних повноважень про обмеження в реалізації права на мирні зібрання справи за позовами про усунення обмежень у реалізації цього права з боку органів виконавчої влади, органів місцевого самоврядування суд має право розглядати це питання у день проведення цих заходів, що сприяє забезпеченню реалізації гарантованого державою права на мирні зібрання громадян, що є позитивним моментом захисту прав на мирні зібрання.
Адміністративна справа про заборону або встановлення обмеження щодо реалізації права на свободу мирних зібрань вирішується судом протягом двох днів після відкриття провадження у справі, а в разі відкриття провадження менш як за два дні до проведення відповідних заходів - невідкладно.

Позивач повинен обгрунтувати потребу в обмеженні реалізації права на свободу мирних зібрань у демократичному суспільстві та пропорційність запропонованого в позові способу обмеження [6].

Суд задовольняє вимоги позивача в інтересах національної безпеки та громадського порядку, якщо визнає, що проведення зборів, мітингів, походів, демонстрацій чи інших зібрань може створити реальну небезпеку заворушень чи вчинення кримінальних правопорушень, загрозу здоров'ю населення або правам і свободам інших людей. У разі встановлення обмеження права на свободу мирних зібрань суд повинен обгрунтувати у постанові потребу у встановленні обмеження щодо реалізації права на свободу мирних зібрань, а також пропорційність способу такого обмеження [1].

Тому проведений нами аналіз рішень окружних адміністративних судів у сфері спорів щодо забезпечення громадського порядку та безпеки, національної безпеки та оборони України, зокрема й зі спорів щодо проведення зборів, мітингів, походів і демонстрацій обмеження та щодо реалізації права на мирні зібрання, дає можливість через призму винесених судових рішень мати уявлення про судову практику з цього питання та визначити динаміку ухвалених рішень.

Так, наприклад, 01 жовтня 2020 року Черкаський окружний адміністративний суд одноособово (в складі головуючого судді А.М. Бабич, за участю: секретаря судового засідання А.С. Виноградової, представника позивача В.В. Гребінного (згідно з посадою), відповідача ОСОБА_1.) розглянув у відкритому судовому засіданні в залі суду за правилами загального позовного (термінового) провадження адміністративну справу № 580/4243/20 за позовом Орловецької сільської ради до ОСОБА_1 про обмеження на мирне зібрання, а саме проведення мирної ходи вулицею Цвітківською с. Орловець Городищенського району Черкаської області з подальшим проведенням мітингу.

У цій справі судом було винесено рішення відмовити повністю в задоволені позову Орловецької сільської ради у забороні на проведення ОСОБА 1 та іншим учасникам 02 жовтня 2020 в період із 17 год 00 хв. до 24 год 00 хв. мирну ходу на вулиці Цвітківській с. Орловець Городищенського району Черкаської області з подальшим проведенням мітингу [7].

Справа, що привернула увагу та викликала гучний соціальний резонанс, також знайшла своє відлуння в м. Київ біля будівлі Національного банку України. Вона була розглянута 
03 лютого 2020 року в м. Дніпрі (провадження № 160/1297/20) суддею Дніпропетровського окружного адміністративного суду Юрковим Е.О., дослідивши матеріали позовної заяви Виконавчого комітету Дніпровської міської ради до Первинної організаційної профспілки трудящих металургів і гірничодобувної промисловості України в Акціонерному товаристві «Нікопольський завод феросплавів» та висунувши вимогу про обмеження права на проведення масового заходу.

Під час судового засідання стало відомо, що 31 січня 2020 року об 18 годині 17 хвилин до Дніпропетровського окружного адміністративного суду засобами електронного поштового зв'язку на офіційну електронну адресу надійшов позов Виконавчого комітету Дніпровської міської ради до Первинної організаційної профспілки трудящих металургів і гірничодобувної промисловості України в Акціонерному товаристві «Нікопольський завод феросплавів», у якому органи виконавчої влади висувають вимоги щодо обмеження права на мирне зібрання Первинної організаційної профспілки трудящих металургів і гірничодобувної промисловості України в Акціонерному товаристві «Нікопольський завод феросплавів» шляхом заборони проведення у період із 03 лютого 2020 до 28 лютого 2020 року масових публічних заходів, а саме проведення пікетування біля приміщень АТ КБ «ПРИВАТБАНК» у м. Дніпро з використанням звукопідсилювальної апаратури, гучномовців, мікрофонів, а також інших засобів, що створюють шум.

Після розгляду суд постановив позовну заяву Виконавчого комітету Дніпровської міської ради до Первинної організаційної профспілки трудящих металургів і гірничодобувної промисловості України в Акціонерному товаристві «Нікопольський завод феросплавів» (третіми особами було залучено: Головне управління Національної поліції в Дніпропетровській області, Акціонерне товариство "Акціонерний комерційний банк «Приватбанк», Дніпропетровський центр професійно-технічної освіти державної служби зайнятості Дніпровської міської ради) про обмеження права на проведення масового заходу. Суд виніс рішення залишити без розгляду справи [9].

Київський окружний адміністративний суд 06 листопада 2019 року розглянув у відкритому судовому засіданні за правилами спрощеного позовного провадження адміністративну справу № 320/6085/19 за позовом Білоцерківської міської ради Київської області до Громадської організації офіцерів м. Біла Церква про встановлення обмеження щодо реалізації права на свободу мирних зібрань та встановив, що 05 листопада 2019 року о 15 год. 00 хв. Білоцерківська міська рада Київської області звернулась до суду з позовом до Гро- мадської організації офіцерів м. Біла Церква про встановлення обмеження щодо реалізації права на свободу мирних вібрань Громадській організації офіцерів м. Біла Церква шляхом заборони проведення «мітингу 07 листопада 2019 року на честь 102 роковини Великої жовтневої революції».

За результатами розгляду суд виніс рішення задовольнити адміністративний позов (установити обмеження щодо реалізації права на свободу мирних зібрань Громадській організації офіцерів м. Біла Церква, шляхом заборони проведення «мітингу 7 листопада 2019 року на честь 102 роковини Великої жовтневої революції») [10].

Суддя Київського окружного адміністративного суду А.О. Кушнова, 20 червня 2019 року розглянувши в порядку письмового провадження матеріали позовної заяви у справі № $320 / 3140 / 19$ Гостомельської селищної ради Київської області до ОСОБА 1 голови Спілки воїнів-учасників АТО смт. Гостомель про встановлення обмеження щодо реалізації права на свободу мирних зібрань, установила, що 20 червня 2019 року о 16 год. 05 хв. Гостомельська селищна рада Київської області звернулась до суду з позовом до ОСОБА_1 голови Спілки воїнів-учасників АТО смт. Гостомель про встановлення обмеження щодо реалізації права на свободу мирних зібрань, заборони проведення зборів, мітингів, акцій, пікетів, походів, демонстрацій тощо за адресою АДРЕСА_1 - Покровська, 220 в селищі Гостомель Київської АДРЕСА_2.

Позовну заяву Гостомельської селищної ради Київської області до ОСОБА_1 голови Спілки воїнів-учасників АТО смт. Гостомель про встановлення обмеження щодо реалізації права на свободу мирних зібрань суд постановив залишити без розгляду, що визначає позицію суду до об’єктивного розгляду та забезпечення права громадянам на проведення мітингу [11].

17 травня 2019 р. Харківський окружний адміністративний суд у складі головуючого судді В.В. Єгупенка, за участю секретаря судового засідання H.Е. Чайкіної розглянув у відкритому судовому засіданні у приміщенні Харківського окружного адміністративного суду адміністративний позов № 520/4785/19 Харківської міської ради до ОСОБА_3 про обмеження права на мирне зібрання.

У процесі розгляду стало відомо, що 16 травня 2019 року Харківська міська рада звернулася до Харківського окружного адміністративного суду з вищевказаним позовом, у якому з урахуванням змін предмета позову просила обмежити право на свободу мирних зібрань шляхом заборони проведення гр. ОСОБА_3 використання та встановлення намету або інших споруд під час проведення безстрокового мирного зібрання на майдані Свободи напроти будівлі Харківської обласної державної адміністрації у м. Харкові. 
У задоволенні адміністративного позову Харківської міської ради до ОСОБА_3 щодо обмеження права на мирне зібрання суд виніс рішення відмовити, що підкреслюе конституиійність позиції проведення мирних зібрань [12].

Із проведеного аналізу судових рішень щодо розгляду та вирішення адміністративних справ щодо реалізації права на мирні зібрання вбачається, що суд виносить різні рішення як із відмовою в задоволенні позову чи залишенні без розгляду, так і для задоволення позовних вимог чи залишення без руху.

Тобто з цих даних можна побачити недостатню підготовленість із практичного боку у вирішенні питань проведення чи заборони мирних мітингів та інших мирних зібрань не тільки через малу кількість ситуацій, недосконалість та прогалини, які штучно створюються під час прийняття законодавчої бази, котрі суд в подальшому може навмисно використовувати для винесення нецивілізованих рішень. Ухвалення зазначених рішень зумовлює негативні наслідки в майбутньому для суспільного порядку та національного розвитку в цілому.

Основним моментом $є$ тривалість та складність судової реформи, рудоменталізм та неприйнятність принципово та безповоротно судової влади як самостійної та незалежної.

Тому зосереджуємо увагу на врегулюванні недопущення управлінських обмежень представниками органів державної влади права на мирні зібрання в умовах законодавчої невизначеності.

\section{Jimepamypa}

1. Кодекс адміністративного судочинства України. Відомості Верховної Ради України. 2005. № 35-36, № 37. ст. 466

2. Кодекс України про адміністративні правопорушення : прийн. 7 груд. 1984 р. Відомості Верховної Ради Української РСР . 1984. Додаток до № 51. Ст. 1122.

3. Узагальнення судової практики розгляду справ за адміністративними позовами суб'єктів владних повноважень щодо обмежень у реалізації права на мирні зібрання та позовами про усунення обмежень у реалізації права на мирні зібрання. URL: https://apladm.zt.court.gov.ua/sud9109/pokaznikidiyalnosti/analitics17/yzagal1517

4. У пошуках шляхів ефективного виконання судових рішень. URL: https://yur-gazeta.com/dumkaeksperta/u-poshukah-shlyahiv-efektivnogo-vikonannyasudovih-rishen.html (дата звернення: 09.10.2020).

5. Виконання судових рішень в Україні: стан, проблеми, міжнародні аспекти. Наиіональна безпека $i$ оборона. 2019. № 3-4. URL: https://razumkov.org.ua/ uploads/journal/ukr/NSD179-180_2019_ukr.pdf (дата звернення: 09.10.2020).

6. Про виконання рішень та застосування практики Європейського суду з прав людини : Закон України від 23.02.2006 № 3477-IV.URL: https://zakon.rada.gov.ua/ laws/show/3477-15 (дата звернення: 09.10.2020).

7. Шуміло 0.0., Аракелян А.Д. Проблеми виконання судових рішень в умовах реформування системи юстиції України. Юридичний науковий електронний журнал. 2017. № 6. С. 280-283.
8. Справа № 580/4243/20 // Єдиний державний реєстр судових рішень. URL: https://reyestr.court.gov. ua/Review/91953009

9. Справа № 160/1297/20 // Єдиний державний реєстр судових рішень. URL: https://reyestr.court.gov. ua/Review/87318613

10. Справа № 320/6085/19 // Єдиний державний реєстр судових рішень. URL: https://reyestr.court.gov. ua/Review/85421651

11. Справа № 320/3140/19 // Єдиний державний реєстр судових рішень. URL: https://reyestr.court.gov. ua/Review/82493962

12. Справа № 520/4785/19 // Єдиний державний реєстр судових рішень. URL: https://reyestr.court.gov. ua/Review/81792602

13. Справа № 160/7677/18 // Єдиний державний реєстр судових рішень. URL: https://reyestr.court.gov. ua/Review/77118019

\section{Анотація}

Кобрусєва Є. А. Особливості провадження щодо розгляду та вирішення адміністративних справ щодо реалізації права на мирні зібрання. - Стаття.

Статтю присвячено дослідженню особливостей провадження щодо розгляду та вирішення адміністративних справ щодо реалізації права на мирні зібрання, адміністративно-правового забезпечення права на мирні зібрання.

Проілюстровано аналіз судових рішень, оскільки законодавець наділив повноваженнями встановлювати обмеження щодо реалізації права на мирні зібрання тільки суд, який може скористатися ними відповідно до Конституції України лише в інтересах національної безпеки і публічного порядку.

У дослідженні наголошено на важливості забезпечення права на мирні зібрання та актуальності питання виконання судових рішень у разі відкриття проваджень щодо обмеження права на мирні зібрання, розгляд яких зараховано до компетенції суду.

Географічно-політичне місце України у двигуні європейських перегонів великої політики диктує не зовсім простий (а подеколи й трагічний) шлях соціально-політичного руху соціуму громадян - брати безпосередню участь у вирішенні економічних та соціальних програм.

Ураховуючи процеси становлення держави та тривалого реформування різних державних інституцій, свобода та право громадян на мирні зібрання ставить перед органами влади питання відповідності активності громадян у вирішенні своєї участі на державному та регіональному рівнях, відстоювання своїх інтересів шляхом вираження та донесення поглядів та незгоди до державних та місцевих структур влади. Постає питання законодавчого та практичного регулювання такого болісного питання, як відносини влади та суспільства, шляхом урегулювання проведення мирних зібрань та активних («без зброї») акцій впливу на державні установи різного рівня.

Спираючись на міжнародний досвід урегулювання права на мирні зібрання, запропоновано шляхи підвищення ефективності механізму адміністративно-правового забезпечення права на мирні зібрання, які полягають у створенні внутрішньодержавного механізму контролю над дотриманням міжнародних стандартів прав та свобод людини, а також розвитку можливостей звернення до Європейського суду з прав людини, якщо та чи інша проблема не вирішена на національному рівні. Доведено, що навіть досить невелике коло чинних норм, що закріплені у законодавчих актах різ- 
ного рівня, які гарантують забезпечення права на мирні зібрання, часто виявляють певну неузгодженість у змісті окреслених прав, особливо з позицій суб'єктів права на свободу мирних зібрань: Конституція України таким суб'єктом називає громадянина, а цивільне законодавство - фізичну особу. Доведено потребу у впровадженні міжнародних стандартів забезпечення права на мирні зібрання, насамперед стандартів європейської спільноти, що пов'язано з євроінтеграційними прагненнями України. Адже впровадження європейських стандартів і дотримання їх суб'єктами публічної адміністрації є однією з передумов інтеграції України в європейський правовий простір.

Ключові слова: мирні зібрання, міжнародні стандарти, суб'єкти забезпечення права на мирні зібрання, громадянське суспільство.

\section{Summary}

Kobrusieva Ye. A. Peculiarities of proceedings on consideration and resolution of administrative cases concerning the exercise of the right to peaceful assembly. Article.

The article is devoted to the study of the peculiarities of the proceedings for consideration and resolution of administrative cases concerning the exercise of the right to peaceful assembly, administrative and legal support of the right to peaceful assembly.

The study emphasizes the importance of enforcement of court decisions that have entered into force.

The changes taking place in Ukrainian society arouse high activity and the desire of people to take a direct part in solving problems that concern their common interests, including the use of the right to peaceful assembly. However, despite the importance of this type of political rights, the constitutional provisions on freedom of assembly, assembly, street demonstrations and demonstrations, which are still not properly specified in the current legislation, are often limited or even violated. Based on the international experience of regulating the right to peaceful assembly, ways to increase the effectiveness of the mechanism of administrative and legal support of the right to peaceful assembly are proposed, which are to create a domestic mechanism to monitor compliance with international standards of human rights and freedoms. human being, if this or that problem is not solved at the national level. It is proved that even a rather small range of current norms enshrined in legislative acts of various levels, which guarantee the right to peaceful assembly, often show some inconsistency in the content of the outlined rights, especially from the standpoint of the right to freedom of peaceful assembly. the subject is called a citizen, and civil law - an individual. The necessity of introduction of international standards of ensuring the right to peaceful assembly, first of all the standards of the European community, which is connected with the European integration aspirations of Ukraine, is proved. After all, the implementation of European standards and their observance by the subjects of public administration is one of the preconditions for Ukraine's integration into the European legal space. Since the right to freedom of peaceful assembly cannot be exercised in the absence of corresponding responsibilities imposed on the state by its authorized bodies, the analysis of the Constitution and laws of Ukraine allowed to separate such bodies into the category of subjects of power to ensure the right to peaceful assembly.

In order to improve the situation in the studied area, it is advisable to review the current legislation, which ensures the implementation of court decisions, to continue reforming public authorities for the effective operation of the judiciary and the protection of citizens' rights.

Key words: peaceful assemblies, international standards, subjects of ensuring the right to peaceful assembly, civil society. 